\title{
Incidence of post-operative hypocalcaemia after thyroidectomy - a retrospective study
}

\author{
S. Raviraj, Y. Vaseethan \\ Department of Surgery, Faculty of Medicine, University of Jaffna, Sri Lanka
}

Key words: Thyroidectomy; post-operative; serum calcium level

\begin{abstract}
Introduction

Post-operative hypocalcaemia following thyroidectomy can lead to distressing symptoms and increase the period of hospitalization. Iatrogenic injury to parathyroid glands is the primary cause for hypocalcaemia.
\end{abstract}

\section{Aim}

This study aims to describe the incidence of postoperative hypocalcaemia and its demographic distribution.

\section{Method}

A retrospective analysis was made in 240 consecutive patients who had undergone total thyroidectomy in the professorial surgical unit, Teaching Hospital Jaffna. The post-operative calcium level, symptoms and signs of hypocalcaemia were considered and correlated with their demographic details and histology report of the specimen.

\section{Results}

The overall incidence of hypocalcaemia was $10.83 \%(n=26)$. Among them, 96.15\% $(\mathrm{n}=25)$ had transient hypocalcaemia and $88.46 \%$ had symptomatic hypocalcaemia $(n=23)$ with biochemical evidence of hypocalcaemia. The rate of inadvertent parathyroidectomy was $6.25 \%$.

\section{Conclusion}

Hypocalcaemia is common in the first three days of postoperative period and most of the hypocalcaemic events are transient.

\footnotetext{
Correspondence: S. Raviraj

E-mail: dr.s.raviraj@gmail.com

Received: 08-06-2017 Accepted: 24-12-2017

(iD) http://orcid.org/0000-0001-6893-2662

DOI: http://doi.org/10.4038/sljs.v35i4.8438
}

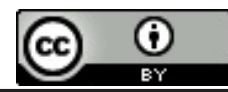

\section{Introduction}

Thyroidectomy is a common operation in Sri Lanka, including the northern region. The incidence of postoperative hypocalcaemia has not been analysed in northern region. The aim of this study is to describe the incidence of hypocalcaemia after total thyroidectomy and its demographic distribution.

Post-operative hypocalcaemia is frequently seen within the first few days after total thyroidectomy $[1,2]$. It is most often transient and may indicate iatrogenic injury to parathyroid gland $[1,2]$. The incidence of inadvertent parathyroidectomy was reported to be $12-16.4 \%$ in the literature. The risk factors include total thyroidectomy, extra thyroidal extension and thyroiditis $[1,2,3]$. The response to calcium replacement therapy for transient hypocalcaemia after thyroidectomy can be seen in a few days to weeks [4]. The persistent hypocalcaemia after 6 months of thyroidectomy is considered permanent hypocalcaemia [5]. The incidence of permanent hypocalcaemia is less than $1-2 \%[6,7]$.

Hypocalcaemia may be asymptomatic or symptomatic depending on the serum calcium level. Chvostek's and Trousseau's signs, paraesthesia and muscle spasm are clinical manifestations of hypocalcaemia [8].

\section{Materials and Methods}

A retrospective analysis was carried out in the professorial surgical unit of Teaching Hospital Jaffna from 1st January 2011 to 1 st July 2016. Data of consecutive patients who underwent thyroidectomy during this period were collected. The inclusion criteria were patients who underwent total, near total or completion thyroidectomy. Exclusion criteria were previous history of parathyroid diseases, renal insufficiency, patients with preoperative calcium replacement therapy and abnormal pre-operative calcium level. Data collected include age, sex, indication for thyroidectomy, pre and post-operative serum calcium level, the presence of postoperative symptoms and signs of hypocalcaemia and the histology report of the specimen. Serum calcium levels in these patients were monitored preoperatively and postoperatively daily up to day six and then weekly up to six weeks. Thereafter serum calcium level was monitored monthly in patients whose calcium levels were low after six weeks. Hypocalcaemia was defined as the corrected calcium level below $8.5 \mathrm{mg} / \mathrm{dl}$. Permanent 
hypocalcaemia was defined as persistent hypocalcaemia after 6 months of thyroidectomy.

Data were entered and analysed using the statistical package for social science (SPSS) and the results were expressed as a percentage, mean, standard deviation and ratio. This study is approved by the Ethical Review Committee, Faculty of Medicine, University of Jaffna.

\section{Result}

A total of 240 patients were included in our study. The number of patients who underwent thyroidectomy and their diagnosis is listed in table 1 .

All patients had pre-operative normal calcium levels. The overall incidence of hypocalcaemia was $10.83 \%(n=26)$. Symptomatic hypocalcaemia was observed in $88.46 \%(\mathrm{n}=23)$ of patients with evidence of biochemical hypocalcaemia. The details of frequency of hypocalcaemia, the age and gender distribution are indicated in tables 2 and 3.

The onset of hypocalcaemia after thyroidectomy is indicated in table 4. The hypocalcaemia in these patients was managed with calcium supplements and Vitamin D. Transient hypocalcaemia was noted in 25 patients and one patient suffered from permanent hypocalcaemia. The time of recovery for patients with transient hypocalcaemia is shown in table 5 .

The histopathology reports revealed accidental removal of parathyroid glands in 15 patients $(6.25 \%)$.Of these 15 patients, 4 developed hypocalcaemia. Among these 4 patients two parathyroid glands have been removed in 3 patients and one removed in 1 patient. Permanent hypocalcaemia was noted in one patient after thyroidectomy with accidental removal of 2 parathyroid glands. Nine patients with accidental removal of one parathyroid gland and 2 patients with removal of two parathyroid glands did not develop hypocalcaemia.

\section{Discussion}

The overall incidence of postoperative hypocalcaemia in this study is $10.8 \%$. The incidence of hypocalcaemia was $10-46$ $\%$ noted in most of the literatures $[5,7,9]$. Transient hypocalcaemia is a common occurrence after total thyroidectomy [1, $10,11]$. In this study, $96.15 \%$ of hypocalcaemia cases are transient. A patient undergoing total thyroidectomy risks vascular injury to the four parathyroid glands due to the requirement for bilateral dissection [12]. It is recommended that with careful dissection of the blood supply of the

Table 1: Diagnosis of patients underwent thyroidectomy

\begin{tabular}{|l|l|}
\hline Diagnosis & Number of patients \\
\hline Multi nodular goitre (MNG) & 77 \\
\hline Graves & 28 \\
\hline Toxic MNG & 26 \\
\hline Thyroid Malignancy (Solitary) & 58 \\
\hline Thyroid Malignancy (MNG) & 38 \\
\hline Recurrent Goitre & 13 \\
\hline
\end{tabular}

Table 2: Age Distribution of the patients and frequency of hypocalcaemia

\begin{tabular}{|l|l|l|c|l|}
\hline Age Distribution & Number of Patients & Percentage & $\begin{array}{l}\text { Number of patients who } \\
\text { developed hypocalcaemia }\end{array}$ & Percentage \\
\hline$<19$ years & 75 & $31.3 \%$ & 5 & $6.66 \%$ \\
\hline $20-49$ years & 110 & $45.8 \%$ & 14 & $12.72 \%$ \\
\hline$>50$ years & 55 & $22.9 \%$ & 7 & $12.72 \%$ \\
\hline
\end{tabular}

Table 3: Gender distribution of patients and frequency of hypocalcaemia

\begin{tabular}{|l|l|l|l|l|}
\hline Sex & Number of patients & Percentage & $\begin{array}{l}\text { Number of Patients who } \\
\text { developed Hypocalcaemia }\end{array}$ & Percentage \\
\hline Male & 43 & $17.9 \%$ & 5 & $11.62 \%$ \\
\hline Female & 197 & $82.1 \%$ & 21 & $10.65 \%$ \\
\hline
\end{tabular}


Table 4: Time of onset of biochemical hypocalcaemia

\begin{tabular}{|l|l|l|l|l|l|}
\hline Post-Operative Day & D1 & D2 & D3 & D4 & D5 \\
\hline Number of patients & 3 & 12 & 9 & 1 & 1 \\
\hline Percentage & $1.25 \%$ & $5 \%$ & $3.75 \%$ & $0.4 \%$ & $0.4 \%$ \\
\hline
\end{tabular}

Table 5: Time of recovery of patients with hypocalcaemia.

\begin{tabular}{|l|c|}
\hline Time of recovery & Number of Patients with transient hypocalcaemia \\
\hline First week & 21 \\
\hline Second week & 4 \\
\hline
\end{tabular}

parathyroid glands they can be spared. Ligation of the inferior thyroid artery close to the thyroid capsule is better in preserving the integrity of the parathyroid gland than ligating close to its origin. Identification of parathyroid gland during surgery is an important factor to prevent post-operative hypocalcaemia as described in various literature. Accidental removal of parathyroid gland was observed as $6.25 \%$ in this study as compared to other studies where it was $17.7 \%$ of the patients undergoing total thyroidectomy [6]. It is reported that identification and preservation of less than three parathyroid glands are associated with permanent hypocalcaemia according to the literatures [13]. The removal of two parathyroid glands leads to permanent hypocalcaemia in our study. Most of the patients who developed hypocalcaemia were observed within first three days, which correlates with other studies [6].

\section{Conclusion}

Hypocalcaemia commonly occurs during the first three days of postoperative period. Most of the hypocalcaemic incidences in post-thyroidectomy are transient in nature and will recover within a period of one week.

\section{References}

1. Gonçalves Filho J, Kowalski LP, Surgical complications after thyr-oid surgery performed in a cancer hospital. Otolaryngol Head Neck Surg 2005; 132(3):490-4.

http://dx.doi.org/10.1016/j.otohns.2004.09.028

2. Khairy G, Al-Saif A. Incidental parathyroidectomy during thyroid resection: incidence, risk factors, and outcome. Annals of Saudi medicine. 2011 May 1;31(3):274. https://doi.org/10.4103/0256-4947.81545

3. Abboud B, Sleilaty G, Braidy C, Zeineddine S, Ghorra C, Abadjian G, Tabchy B. Careful examination of thyroid specimen intraoperatively to reduce incidence of inadvertent parathyroid-ectomy during thyroid surgery. Archives of Otolaryngo-logy-Head \& Neck Surgery. 2007 Nov 1; 133 (11) : 1105-10. https://doi.org/10.1001/archotol.133.11.1105
4. Bentrem DJ, Rademaker A, Angelos P. Evaluation of serum calcium levels in predicting hypoparathyroidism after total/ near-total thyroidectomy or parathyroidectomy. Am Surg 2001; 67:249-51 https://www.ncbi.nlm.nih.gov/pubmed/11270883

5. Abboud B, Sargi Z, Akkam M, et al. Risk factors for post thyroidectomy hypocalcemia. J Am Surg 2002;195:456-61. https://doi.org/10.1016/S1072-7515(02)01310-8

6. Dedivitis RA, Pfuetzenreiter EG, Nardi CE, de Barbara EC. Prospective study of clinical and laboratorial hypocalcemia after thyroid surgery. Brazilian journal of otorhinolaryngology. 2010 Feb 28;76(1):71-7. https://doi.org/10.1590/S1808-86942010000100012

7. Ozogul B, Akcay MN, Akcay G, Bulut OH. Factors affecting hypocalcaemia following total thyroidectomy: a prospective study. Eurasian J Med 2014;46:15-21 https://doi.org/10.5152/eajm.2014.03

8. P.Tredici et al, Identification of patients at high risk for hypocalcaemia after total thyroidectomy. ATCT otorhinolaryngologica italic 2010; 30: 144-148

9. Harness, J.K., Fung, L., Thompson, N.W. et al. Total thyroidectomy: Complications and technique. World J. Surg 1986; 10: 781. https://doi.org/10.1007/BF01655238

10. Güllüoglu BM, Manukyan MN, Cingi A, Yegen C, Yalin R, Aktan AO. Early prediction of normocalcaemia after thyroid surgery. World J Surg 2005;29(10):1288-93. https://doi.org/10.1007/s00268-005-0057-2

11. Sakorafas GH, Stafyla V, Bramis C, Kotsifopoulos N, Kolettis T, Kassaras G. Incidental parathyroidectomy during thyroid surgery: an underappreciated complication of thyroidectomy. World J Surg 2005;29(12):1539-43. https://doi.org/10.1007/s00268-005-0032-y

12. Chia SH, Weisman RA, Tieu D, Kelly C, Dillmann WH, Orloff LA. Prospective study of perioperative factors predicting hypocalcemia after thyroid and parathyroid surgery. Arch Otolaryngol Head Neck Surg 2006;132(1):41-5. https://doi.org/10.1001/archotol.132.1.41

13. Olson JA, DeBenedetti MK, Baumann DS, Wells SA. Parathyroid auto $\neg$ transplantation during thyroidectomy. Results of long-term follow-up. Ann Surg 1996;223(5):472-8; discussion 478-80. https://doi.org/10.1097/00000658-199605000-00003 